\title{
Kritik Sosial dan Nilai Moral dalam Kumpulan Cerpen Lelucon Para Koruptor Karya Agus Noor
}

\author{
Nurul Fajri \\ Universitas Indraprasta PGRI \\ Jalan Nangka No. 58 C/TB. Simatupang, Tanjung Barat, Jakarta Selatan 12530 \\ nurul.fajri11@yahoo.com
}

\begin{abstract}
Social Criticism and Moral Values: in the Short Story Collection Jokes Corruptors by Agus Noor in Building Character Education in Class X Students of SMA 1 Leuwidamar. The purpose of this study was to find out the aspects of social criticism and the moral value of Jokes Corps' collection of short stories in building character education. This research is in the form of descriptive qualitative using content analysis. The data source used is a book collection of short stories Jokes Corruptors. The research sample was taken by reducing half of the number of short stories in the book. Data analyzed in the form of aspects of social criticism include; critique of the relevance of the situation, the attitude of the community / apparatus / government and the attitude of the individual who is selfish / irresponsible. Moral values include social, moral, ethical, and moral. As well as the content of character education values in the form of crystallization of the main character values namely, religious, nationalist, mutual cooperation, integrity and independence. Based on the results of the study obtained the following findings. First, there are 48 aspects of social criticism. Second, the aspects of moral value were 29 findings. Third, the educational value of the character is 17 findings. Fourth, there is relevance in learning Indonesian in class $X$ in the revised edition of the 2013 curriculum in KD 3.8 comparing and KD 4.8 developing.
\end{abstract}

Keywords: Social criticism, moral values, character education, short stories.

\begin{abstract}
Abstrak
Kritik Sosial dan Nilai Moral: dalam Kumpulan Cerpen Lelucon Para Koruptor karya Agus Noor dalam Membangun Pendidikan Karakter pada Siswa Kelas X SMA Negeri 1 Leuwidamar. Tujuan dari penelitian ini adalah untuk mengetahui aspek kritik sosial dan nilai moral kumpulan cerpen Lelucon Para Koruptor dalam membangun pendidikan karakter. Penelitian ini berbentuk kualitatif deskriptif dengan menggunakan analisis isi. Sumber data yang digunakan berupa buku kumpulan cerpen Lelucon Para Koruptor. Sampel penelitian diambil dengan cara mereduksi setengah dari jumlah cerpen dalam buku. Data yang dianalisis berupa aspek kritik sosial meliputi; kritik relevansi keadaan, sikap masyarakat/ aparat/ pemerintah dan sikap individu yang egois/ tidak bertanggung jawab. Nilai moral yang meliputi: sosial, akhlak, etika, dan susila. Serta muatan nilai pendidikan karakter berupa kristalisasi nilai karakter utama yakni, religius, nasionalis, gotong-royong, integritas dan mandiri. Berdasarkan hasil penelitian diperoleh temuan sebagai berikut. Pertama, aspek kritik sosial sebanyak 48 temuan. Kedua, aspek nilai moral sebanyak 29 temuan. Ketiga, nilai pendidikan karakter 17 temuan. Keempat, terdapat relevansi dalam pembelajaran bahasa Indonesia di kelas X dalam kurikulum 2013 edisi revisi pada KD 3.8 membandingkan dan KD 4.8 mengembangkan.
\end{abstract}

Kata Kunci: Kritik sosial, nilai moral, pendidikan karakter, cerpen

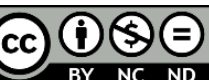

Creative Commons Attribution-NonCommercial-NoDerivatives 4.0 International License 


\section{PENDAHULUAN}

Sastra adalah jenis kesenian yang merupakan hasil kristalisasi nilai-nilai yang disepakati untuk terus menerus dibongkar dan dikembangkan dalam suatu masyarakat. Karena sastra adalah seni bahasa, dibandingkan dengan seni lain, di dalamnya terbayang dengan lebih tegas nilai-nilai yang mengatur kehidupan dan selalu ditinjau kembali. Dengan menggunakan bahasa sastra seorang sastrawan berusaha untuk tidak sekadar merekam kehidupan di sekitarnya, tetapi juga tanggapan evaluatif terhadapnya. Artinya, karya sastra berusaha menawarkan serangkaian pilihan pengalaman dan penghayatan kehidupan bagi masyarakat agar tidak terkurung dalam dunia pengalaman dan penghayatan sehari-hari saja.

Kondisi masyarakat kita sangatlah menjunjung tinggi budaya dan sangat kental dengan kekayaan rohani. Hal itu sejalan dengan definisi karya sastra bahwa karya sastra merupakan pengalaman, kekayaan rohani, kehidupan atau dunia yang portable - bisa dijinjing ke mana-mana. Dunia kesastraan mengenal prosa (prose) sebagai salah satu genre sastra di samping genre-genre yang lain. Untuk mempertegas keberadaan genre prosa, sering dipertentangkan dengan genre yang lain, misalnya dengan puisi, walau pertentangan itu sendiri hanya bersifat teoritis. Seperti halnya dalam kesastraan Inggris dan Amerika, genre prosa menunjukkan pada karya yang berwujud novel, roman dan cerita pendek.

Mochtar Loebis (dalam Sumardjo, 1986:24) mengatakan bahwa yang disebut cerita pendek adalah cerita yang selesai baca, dua kali baca, atau tiga kali baca, dengan jumlah perkataan berkisar antara 500 - 3.000. sebuah cerpen harus mengandung unsur-unsur: 1) interprets pengarang tentang konsepnya mengenai kehidupan, baik secara langsung atau tidak langsung, 2) harus menimbulkan suatu hempasan dalam pemikiran pembaca, 3) harus menimbulkan perasaan pembaca, bahwa pembaca merasa terbawa oleh jalan cerita dan cerita pendek pertama-tama menarik perasaan dan baru menarik pikiran, 4) mengandung perincian insideninsiden yang dipilih dengan sengaja, dan bisa menimbulkan pernyataan-pernyataan dalam pemikiran pembaca.

Jakob Sumardjo (1986:25) merumuskan bahwa cerita pendek harus berupa cerita atau narasi (bukan analisis argumentatif) yang fiktif (tidak benar-benar terjadi, kapan saja, dan di mana saja) serta relatif pendek. Cerita fiktif yang pendek berdasarkan realitas tersebut hanya mengandung satu kejadian untuk efek pembaca.

Perkembangan cerita pendek Indonesia selepas reformasi (1997), agaknya makin mengukuhkan jati dirinya yang memperlihatkan wilayah dan kekuasaannya sendiri. Cerpen tak hanya muncul seperti gelombang yang secara kuantitatif melampaui penerbitan novel dan drama, tetapi juga seperti menempatkan dalam mainstream-nya sendiri. Cerpen lebih padu, lebih —memenuhill tuntutan ke-unityan daripada novel. Karena bentuknya yang pendek, cerpen menuntut penceritaan yang serba ringkas, tidak sampai pada detil-detil khusus yang - kurang penting\| yang lebih memperpanjang cerita.

Kelebihan cerpen yang khas adalah kemampuannya mengemukakan secara lebih baik-jadi, secara implisit-dari sekadar apa yang diceritakan. Karena bentuknya yang pendek, cerpen memiliki karakteristik pemadatan dan pemusatan terhadap sesuatu yangn dikisahkan. Cerita tidak dikisahkan secara panjang lebar 
sampai mendetil, tetapi dipadatkan dan difokuskan pada satu permasalahan saja (Nurgiyantoro, 2013: 13).

Jika mencermati cerpen-cerpen Indonesia yang awal, maka di satu sisi, terbuktilah sudah, bahwa penulisan prosa Indonesia modern dimulai dari cerpen, dan sisi yang lain, menegaskan bahwa kesusastraan Indonesia tidak lahir dari sebuah kekosongan (Mahayana, 2006: 09). Kekosongan ini tidak lepas dari kehidupan masyarakat sebagai kenyataan sosial. Terdapat sejumlah gambaran masyarakat direkam di dalamnya.

Upaya yang dilakukan seorang pengarang untuk memberikan suatu tanggapan terhadap persoalan-persoalan yang dilihat dalam masyarakat adalah melalui karyanya. Tanggapan itu biasanya disertai dengan pertimbangan atau pemikitan pengarang. Pengarang mencoba menyatakan kesalahan atau ketimpangan yang diketahuinya melalui cerita berupa teguran, sindiran bahkan penghakiman dengan tujuan menyadarkan objek sasaran. Tanggapan tersebut yang kemudian disebut sebagai kritik, kritik terhadap lingkungan yang berada disekitar pengarang maupun yang disimaknya.

Pendekatan sosiologis, khususnya untuk sastra Indonesia, baik lama maupun modern menjanjikan lahan penelitian yang tidak akan pernah kering. Setiap hasil karya, baik dalam skala angkatan maupun individu, memiliki aspek-aspek sosial tertentu yang dapat dibicarakan melalui model-model pemahaman sosial (Ratna, 2009: 60-61). Berbeda halnya dengan pandangan Wallek \& Warren (1993: 110) menuturkan bahwa pendekatan sosiologis ini terutama dipakai oleh pendukung filsafat sosial tertentu. Kritikus aliran Marxisme tidak hanya mempelajari kaitan sastra dengan masyarakat, tetapi juga memberi batasan bagaimana seharusnya hubungan itu dalam masyarakat zaman sekarang dan masyarakat di masa yang akan datang yang tidak mengenal kelas.

Sosiologi sastra berasal dari kata sosiologi dan sastra. Pada dasarnya, ilmu sosiologi sastra memiliki objek yang sama, yaitu manusia dalam masyarakat. Endraswara (2008:5) berpendapat bahwa - Sosiologi sastra adalah ilmu yang memanfaatkan faktor sosial sebagai pembangun sastra

Masalah-masalah kemasyarakatan dalam karya sastra tidak sederhana, sangat kompleks seperti juga kekompleksan masyarakat dalam kehidupan nyata ini. Karena itulah, dapat dipahami pendapat yang mengatakan bahwa karya sastrasalah satunya disini cerpen - yang besar pada umumnya adalah karya sastra yang bersifat sosial, konflik antar tokoh, yang pada dasarnya menunjukkan benturan antar individu, kelompok, dan masyarakatnya. Hal ini disebabkan oleh adanya hubungan langsung sejumlah peralatan sastra, seperti bahasa sebagai alat pengungkapan yang pada dasarnya adalah milik masyarakat.

Kondisi bangsa yang kiat carut marut, membuat berbagai kalangan menjadi khawatir. Terutama pihak yang bergerak dalam dunia pendidikan. Di berbagai media menganggap gurulah yang harus bertanggung jawab atas kondisi bangsa ini. Itu bukanlah pernyataan yang keliru, namun rasanya tidak adil bila hanya mengkambinghitamkan guru, sebab pada dasarnya ruang lingkup pendidikan bukan hanya lingkungan sekolah.

Tarigan dalam Rahmawati (2015: 19) menjelaskan, kata kritik yang lazim kita pergunakan dalam bahasa Indonesia berasal dari bahasa Yunani — krinein\| 
yang berarti - mengamati, membanding dan menimbang. Kritik sosial adalah salah satu bentuk komunikasi dalam masyarakat yang bertujuan atau berfungsi sebagai kontrol terhadap jalannya suatu sistem sosial atau proses bermasyarakat. Selain itu, kritik sosial merupakan aktivitas yang berhubungan dengan penilaian, perbandingan, dan pengungkapan, mengenai kondisi sosial suatu masyarakat terkait dengan nilai-nilai yang dianut ataupun nilai-nilai yang dijadikan pedoman. Semua hal itu diamati secara cermat. Dalam hal ini, pengarang memainkan perannya sebagai subjek atau pun pengamat subjek melalui karya yang diciptakannya (Steven, (2014).

Kata sosial dalam KBBI adalah berkenaan dengan masyarakat, suka memeperhatikan kepentingan umum. Poerwadarminto dalam Rahmawati (2015:20), menjelaskan kata sosial berarti: (1) Segala sesuatu mengenai masyarakat atau kemasyarakatan yang bertugas mengurus kesejahteraan dan kebaikan. (2) Sifat sosial berarti suka memperhatikan kepentingan umum. Dari definisi — kritik\| dan - sosiall tersebut dapat ditarik sebuah kesimpulan bahwa yang dimaksud kritik sosial adalah tanggapan baik atau buruknya kualitas suatu karya sastra yang berhubungan dengan masyarakat.

Tentang kritik sosial, Rendra dalam Rahmawati (2015: 20) menyatakan bahwa kewajiban seorang penyair untuk mengkritik semua operasi di masyarakat, baik yang bersifat secular maupun spiritual yang menyebabkan di dalam kehidupan kesadaran, sebab kemacetan kesadaran adalah kemacetan daya cipta, kemacetan daya hidup, dan melemahkan daya pembangunan. Sastra mencerminkan persoalan sosial yang ada dalam masyarakatnya, dan kalau pengarang memiliki taraf kepekaan yang tinggi, karya sastranya pasti mencerminkan kritik sosial yang ada dalam masyarakat itu.

Rendra dalam Rahmawati (2015: 15) menjelaskan bahwa kita dapat dan perlu memahami kritik sosial para penyair sebagai masukan untuk menyegarkan kehidupan kemasyarakatan, kebangsaan dan kenegaraan. Hal tersebut senada dengan Nurgiyantoro (2013: 331) menegaskan bahwa sastra yang mengandung pesan kritik biasanya akan lahir di tengah masyarakat jika terjadi hal-hal yang kurang beres dalam kehidupan sosial dalam masyarakat. Kritik sosial yang dilontarkan lewat karya sastra bisa mencakup segala macam kehidupan sosial di negeri ini, sebagai contoh hubungan manusia dengan lingkungannya, manusia lain, kelompok sosial, penguasa dan institusi.

Pendidikan merupakan hal pokok untuk membentuk peradaban. Sebab baik tidaknya kondisi suatu bangsa bergantung bagaimana pendidikan di keluarga, sekolah dan masyarakat dikelola dengan baik. Jika tidak, maka terjadilah berbagai bencana alam, kerusakan moral, kezaliman, dan kerusakan tatanan hukum. Semua kerusakan itu membuktikan bahwa peradaban sudah berubah.

Pembenahan terhadap perubahan sosial yang timpang dan carut-marut ini bisa dimulai dari pendidikan karakter. Pendidikan karakter merupakan hal yang tidak bisa ditawar lagi. Jika bangsa ini menghendaki terciptanya generasi muda yang mampu mencerminkan jati diri bangsa. Bangsa yang punya harga diri, bangsa yang berkarakter, dan bangsa yang bermartabat.

Hasil penelitian yang dilakukan Komisi Nasional Anak di kota-kota besar di Indonesia melaporkan 97\% anak Indonesia pernah menonton pornografi (2009). 
sekitar $62,7 \%$ remaja di Indonesia telah melakukan hubungan seks diluar nikah, $20 \%$ dari 94.270 perempuan yang mengalami hamil diluar nikah dari kelompok usia remaja, dan $21 \%$ diantaranya pernah melakukan aborsi (data tahun 2014).

Kemudian, 25\% kasus bullying dan sisanya permasalahan tawuran pelajar (data tahun 2014). Belum lagi ditambah kasus narkoba. Badan Narkotika Nasional (BNN) menyebutkan jumlah pengguna narkoba di usia remaja naik 14 ribu jiwa dengan rentang usia 12 - 21 tahun (2016). Perilaku hidup yang demikian menjadi karakter masyarakat modern yang pada akhirnya melahirkan kesenjangan sosial yang berkepanjangan.

Pada hakikatnya, nilai-nilai moral atau nilai baik-buruk, positif-negatif, pantas-tak pantas dan sejenisnya adalah bersumber dari ajaran agama. Prinsip ajaran agama adalah untuk mengatur kehidupan manusia. Jenis ajaran moral dapat mencakup masalah, yang boleh dikatakan tak terbatas. Ia dapat mencakup seluruh persoalan kehidupan, seluruh persoalan yang menyangkut harkat dan martabat manusia. Secara garis besar persoalan kehidupan manusia itu dapat dibedakan ke dalam persoalan : (a) persoalan manusia dengan dirinya sendiri, (b) hubungan manusia dengan manusia lain dalam lingkup sosial termasuk dalam hubungannya dengan lingkungan alam, dan (c) hubungan manusia dengan Tuhannya (Nurgiyantoro, 2013:323).

Pengarang melalui karyanya selain menyampaikan kritik sosial, pengarang juga menyampaikan nilai moral yang ada dalam cerpen. Secara umum moral mengacu pada ajaran baik-buruk yang diterima umum mengenai perbuatan, sikap, kewajiban dan sebagainya; akhlak, budi pekerti, susila (Kamus Umum Bahasa Indonesia,2015). Istilah "bermoral" bagi seseorang yang kita rujuk berarti bahwa yang bersangkutan memiliki pertimbangan baik dan buruk, pantas dan tidak pantas, positif dan negatif.

Jika dicermati, untuk mengatasi permasalahan itu, tentu dimulai dari pendidikan. Pendidikan yang tidak hanya fokus pada kognitif, tapi pada akhlak sebagai wujud dari pendidikan karakter. Namun, apa pun kurikulumnya yang terpenting adalah keberadaan pendidikan karakter sebagai bagian dari kurikulum tersebut.

Pendidikan karakter sebenarnya bukan hanya tugas sekolah atau bukan hanya tanggung jawab menteri pendidikan. Pendidikan karakter dapat dilakukan dengan berbagai cara dan oleh siapa saja. Seniman melalui karya-karyanya, sutradara melalui filmnya, penyanyi melalui lagu-lagunya, guru melalui teladannya, dan penulis melalui buku-bukunya, serta masih banyak lagi (Nursyamsi, 2016:04).

Dari berbagai persoalan diatas, perlu rasanya melakukan penelitian tentang bagaimana karya sastra mampu memberikan pembelajaran karakter yang kuat. Karya sastra tidak hanya kreatif dan imajinatif, tetapi juga mengatur dan memberi pengalaman baru yang dapat dibayangkan dalam dunia nyata.

Dengan kata lain, karya sastra yang baik bukanlah sekadar puitis dan menghibur. Tapi, karya yang mampu membuat pembaca terinspirasi. Karya yang dapat memberi pesan moral untuk dapat diteladani dan dimaknai dalam kehidupan sehari-hari, atau bahkan dijadikan pandangan hidup. Dengan beredarnya berbagai bacaan yang tidak layak untuk anak didik, terutama remaja. Guru dan orang tua memiliki peran untuk menyeleksi buku bacaan yang disarankan untuk peserta didik.

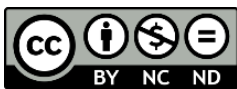

Creative Commons Attribution-NonCommercial-NoDerivatives 4.0 International License 
Hal ini dilakukan agar peserta didik tidak terjerumus. Selain itu, tidak hanya dituntut untuk rajin membaca, tapi peserta didik harus bisa membedakan bacaan yang baik dan tidak baik.

Salah satu karya sastra yang dapat di rekomendasikan dalam pembelajaran apresiasi sastra adalah cerpen. Sebab cerpen menduduki prosa yang paling sederhana. Dan tentunya karya sastra ini harus sesuai dengan karakteristik peserta didik, terutama anak didik SMA sebagai remaja transisi. Maka dibutuhkan karya sastra yang sesuai dengan karakter remaja SMA, dan mampu memberikan teladan serta perenungan.

Salah seorang penulis cerpen penting yang dimiliki negeri adalah Agus Noor, cerpenis terkemuka dalam sastra Indonesia kontemporer, kali ini hadir dengan kumpulan cerpen terbarunya. Mengangkat realitas korupsi di negeri ini, dengan gaya penceritaan yang "tak biasa": Agus Noor gemar mengembangkan kisah-kisah sadis-romantis-magis, di buku ini dia banyak bercanda dengan leluconlelucon yang sangat kocak, sekaligus surreal-komikal.

Lelucon Para Koruptor, cerpen karya Agus Noor yang diluncurkan pada 2017 lalu kini diangkat ke atas pentas dengan lakon berjudul Romantisme dan Kegilaan Agus Noor. Lakon tersebut dipentaskan pada Sabtu (10/2) di Auditorium Galeri Indonesia Kaya. Lakon yang menggambarkan kisah-kisah gila, ganjil dan penuh kelucuan-kelucuan satir dari perilaku para koruptor, berhasil menggetarkan akal sehat para penonton. Agus Noor memang dikenal sebagai penulis yang seringkali berhasil menciptakan anomali dan romantisme yang menggiring pembacanya keluar dari batas-batas umum.

Berdasarkan permasalahan yang dipaparkan di atas, serta dengan melihat pandangan dari berbagai pihak tentang kumcer tersebut. Maka, penulis akan melakukan penelitian terhadap kumcer tersebut. Adapun yang menjadi judul dari tesis yang diajukan adalah -Kritik Sosial, nilai moral, dan Pendidikan Karakter dalam Kumcer Lelucon Para Koruptor Karya Agus Noor (Tinjauan Sosiologi Sastra).

\section{METODE}

Ratna (2012: 34) mengemukakan secara etimologis metodologi berasal dari kata methods dan logos, yaitu filsafat atau ilmu mengenai metode. Metodologi dengan demikian membahas prosedur intelektual dalam totalitas komunitas ilmiah.

Metode yang digunakan dalam penelitian ini adalah metode kualitatif dengan analisis isi (content analysis). Edraswara (2008: 5) mendefinisikan bahwa penelitian kualitatif adalah penelitian yang dilakukan dengan tidak mengutamakan angka-angka, tetapi mengutamakan kedalaman penghayatan terhadap interaksi antar konsep yang sedang dikaji secara empiris.

Metode kualitatif berusaha menyusun model berpikir sebagai penjelas secara deskriptif-naratif yang menggambarkan keterkaitan antara konsep-konsep kunci yang secara integral merupakan manifestasi fokus permasalahan. Penelitian ini bertujuan untuk menjelaskan kritik dan nilai karakter yang terdapat dalam kumpulan cerpen Lelucon Para Koruptor. Adapun cerpen yang dijadikan Temuan 
dalam penelitian ini adalah ke-12 cerpen dalam kumcer tersebut sekaligus sebagai data primer. Penelitian dikaji dengan menggunakan pendekatan sosiologi sastra.

Rangkaian cerita dalam cerpen-cerpen Lelucon Para Koruptor menunjukkan gejala-gejala sosial yang terjadi pada remaja dalam pencarian jati diri. Melalui kajian sosiologi sastra diharapkan akan terungkap bentuk kritikan dan nilai pendidikan karakter dari gejala-gejala itu. Sehingga yang terungkap dalam pepatah Latin, bahwa karya sastra itu harus mempunyai nilai utile et dulce (Taufiqurohman, 2016: 29).

\section{HASIL DAN PEMBAHASAN}

Setelah melakukan analisis pada kumpulan cerpen Lelucon Para Koruptor, penulis menemukan temuan yang mengarah pada kritik sosial, di antaranya relevansi keadaan, sikap masyarakat/ aparat/ pemerintah dan sikap individu yang egois/ tidak bertanggung jawab. Dengan uraian, relevansi keadaan terdapat sebanyak 3 Temuan. Temuan tersebut antara lain, 1 Temuan pada judul Lelucon Para Koruptor, 1 Koruptor Kita Tercinta dan 1 pada judul Perihal Orang Miskin yang Bahagia. Setelah melakukan analisis terhadap kumpulan cerpen Lelucon Para Koruptor (LPK), penulis menemukan kutipan yang mengarah pada kritikan terhadap sikap aparat/pemerintah/masyarakat, yaitu sebanyak 37 temuan. Dengan rincian: 4 Temuan Lelucon Para Koruptor, 12 Temuan Koruptor Kita Tercinta, 12 Temuan Perihal Orang Miskin yang Bahagia, dan 9 Desas-desus Politisi yang Memakai Kacamata Hitam. Setelah dilakukan analisis, maka terdapat temuan yang mengarah pada kritikan terhadap sikap sombong /egois/tidak bertanggung jawab. Temuan tersebut sebanyak 8 temuan dengan rincian, 3 Temuan Lelucon Para Koruptor, 1 Temuan Koruptor Kita Tercinta, 1 Temuan Perihal Orang Miskin yang Bahagia, dan 3 Desas-desus tentang Politisi yang selalu Memakai Kacamata Hitam.

Setelah melakukan analisis pada kumpulan cerpen Lelucon Para Koruptor, penulis menemukan temuan yang mengarah pada nilai moral, yang meliputi nilai sosial, akhlak, etika, dan susila dengan rincian nilai sosial sebanyak 15 temuan, dengan rincian 1 Lelucon Para Koruptor, 3 Temuan Koruptor Kita Tercinta, 7 Temuan Perihal Orang Miskin yang Bahagia, dan 4 Desas-desus tentang Politisi yang selalu Memakai Kacamata Hitam. Setelah melakukan analisis terhadap kumpulan cerpen Lelucon Para Koruptor (LPK), penulis menemukan kutipan yang mengarah pada nilai sosial. Temuan tersebut sebanyak 7 temuan. Dengan rincian, 1 Lelucon Para Koruptor, 3 Temuan Koruptor Kita Tercinta, 1 Temuan Perihal Orang Miskin yang Bahagia, dan 2 Desas-desus tentang Politisi yang selalu Memakai Kacamata Hitam. Setelah melakukan analisis terhadap kumpulan cerpen Lelucon Para Koruptor (LPK), penulis menemukan kutipan yang mengarah pada nilai etika. Temuan tersebut sebanyak 2 Temuan yang hanya terdapat pada cerpen Lelucon Para Koruptor (LPK). Setelah melakukan analisis terhadap kumpulan cerpen Lelucon Para Koruptor (LPK), penulis menemukan kutipan yang mengarah pada nilai susila. Temuan tersebut sebanyak 5 temuan. Dengan rincian, 2 Lelucon Para Koruptor, 1 Temuan Koruptor Kita Tercinta, 1

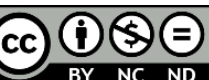

Creative Commons Attribution-NonCommercial-NoDerivatives 4.0 International License 
Temuan Perihal Orang Miskin yang Bahagia, dan 1 Desas-desus tentang Politisi yang selalu Memakai Kacamata Hitam.

Setelah melakukan analisis pada kumpulan cerpen Lelucon Para Koruptor, penulis menemukan temuan yang mengarah pada pendidikan, meliputi religius, nasionalis, gotong-royong, integritas dan mandiri. Adapun rinciannya, karakter gotong royong sebanyak 3 temuan, dengan rincian 2 Temuan Koruptor Kita Tercinta dan 1 Temuan Perihal Orang Miskin yang Bahagia. Setelah melakukan analisis terhadap kumpulan cerpen Lelucon Para Koruptor, penulis menemukan kutipan yang membangun pendidikan karakter integritas. Temuan tersebut sebanyak 8 temuan, yaitu 1 Temuan Lelucon Para Koruptor, 6 Temuan Koruptor Kita Tercinta dan 1 Temuan Desas-desus Tentang Politisi yang Selalu Mengenakan Kacamata Hitam. Setelah melakukan analisis terhadap kumpulan cerpen Lelucon Para Koruptor, penulis menemukan kutipan yang membangun pendidikan karakter mandiri. Temuan tersebut sebanyak 1 Temuan.

Setelah menganalisis kumpulan cerpen Lelucon Para Koruptor dari segi aspek kritik sosial, nilai moral, dan pendidikan karakter. Tahap selanjutnya ialah melakukan pengajaran cerpen Lelucon Para Koruptor pada siswa kelas X MIPA 1, $X$ MIPA 2, X MIPA 3, dan X IPS 1 dengan jumlah siswa 125 siswa. Dalam proses pembelajarannya, siswa disajikan teks cerpen Lelucon Para Koruptor untuk dibaca. Setelah itu, siswa diberikan lima butir pertanyaan berkaitan dengan teks tersebut. Berikut pertanyaannya:

1. Uraikanlah pesan moral yang terdapat dalam cerpen tersebut?

2. Pembelajaran apa yang bisa diambil dari cerpen tersebut?

3. Apakah kalian ingin seperti tokoh yang ada dalam cerpen tersebut?

4. Kalau kalian jadi pejabat, apa yang kalian lakukan?

5. Apa pendapat kalian tentang korupsi?

Dari pertanyaan di atas diperoleh data sebagai berikut:

\section{Uraikanlah pesan moral yang terdapat dalam cerpen tersebut?}

Semua siswa menjawab, bahwa dalam cerpen tersebut mengandung pesan moral. Beberapa alasan yang diungkapkan siswa, diantaranya: sikap saling menghargai, janganlah menjadi seorang koruptor, jangan menutupi fakta kebenaran, jangan menyalahgunakan jabatan, jangan melihat seseorang dari jabatannya, dan jangan menutupi kebenaran di depan hukum. Dari data di atas, siswa dapat mengambil nilai moral yang terkandung dalam cerpen Lelucon Para Koruptor dan dapat mengaplikasikannya dalam kehidupan sehari-hari, sehingga di masa akan datang mereka dapat bersikap jujur dan tidak merugikan orang lain.

2. Pembelajaran apa yang bisa diambil dari cerpen tersebut?

Adapun kompilasi jawaban yang siswa berikan terkait soal tersebut, diantaranya: jangan menyalahgunakan jabatan untuk korupsi, orang yang bersalah pun masih bisa tertawa, tidak boleh melipat hak orang lain, menjadi orang yang jujur dan kepemimpinan, tanggung jawab terhadap jabatan dan tugas, perbuatan yang tidak patut dicontoh, tidak membenci dan saling mengingatkan, menerima konsekuensi atas kesalahan, dan bekerja keras tanpa korupsi. Dari uraian jawaban siswa tersebut, dapat diketahui bahwa siswa 
memperoleh pembelajaran berkaitan dengan tindakan korupsi. Bahwa perbuatan korupsi adalah perbuatan yang tidak patut ditiru oleh generasi muda. Untuk itu korupsi harus dimusnahkan di negeri ini.

3. Apakah kalian ingin seperti tokoh yang ada dalam cerpen tersebut?

Atas pertanyaan tersebut, semua siswa menjawab tidak ingin seperti tokoh yang ada dalam cerpen tersebut. Adapun alasan yang mereka ungkapkan ialah, korupsi itu haram dilarang agama, merugikan diri sendiri, keluarga, dan negara, karena mengambil hak rakyat, bukan perilaku terpuji, hidupnya tidak tenang, akan dihukum dan dipenjara, menjatuhkan harkat dan martabat. Dari uraian jawaban siswa tersebut, mereka sepakat tidak ingin menjadi seorang koruptor. Koruptor dapat memberikan efek keburukan yang sangat besar bagi kehidupan. Tidak patutu seseorang mendapatkan kekayaan dengan jalan mengambil hak rakyat. Mereka lebih baik hidup sederhana tapi berkah, dari pada hidup mewah tetapi hasil korupsi.

4. Kalau kalian menjadi pejabat, apa yang akan kalian lakukan?

Beragam jawaban yang siswa berikan terkait pertanyaan tersebut, diantaranya: tidak akan korupsi, ingin memajukan negara yang adil dan beradab, akan membuat lapangan pekerjaan, akan membangun jalan yang rusak, akan mendirikan industri, menjadi pejabat yang jujur, bertanggung jawab, dan menjalankan tugas dengan baik, mendirikan sekolah gratis, membantu masyarakat yang miskin, dan membangun fasilitas olah raga, harapan mereka sangatlah tinggi ketika diberikan gambaran menjadi seorang pejabat. Mereka ingin membawa negeri ini lebih maju, menyejahterakan masyarakat, dan tanggung jawab terhadap tugas. Mereka tidak ingin ketika kelak menjadi pejabat seperti pejabat yang sekarang, yaitu memperkaya diri sendiri dengan jalan korupsi.

5. Apa pendapat kalian tentang korupsi?

Adapun kompilasi jawaban yang siswa berikan terkait soal tersebut, diantaranya: korupsi menyebabkan masyarakat susah, korupsi menyebabkan kerugian negara, korupsi perbuatan yang tidak jujur, korupsi perbuatan haram, korupsi harusnya bukan perbuatan seorang pejabat, dan korupsi harus diberantas. Dari uraian jawaban tersebut, siswa menginginkan negara ini bebas dari korupsi. Korupsi sangat merugikan semua pihak, begitu pn bagi si pelakunya.

Melalui proses pengajaran cerpen Lelucon Para Koruptor, siswa dapat memahami tentang korupsi dan para pelakunya ketika di penjara. Pemahaman itulah yang dapat membangun karakter siswa dalam kehidupan sehari-hari bahkan di masa yang akan datang. Kelak mereka ditakdirkan sebagai pejabat yang jujur dan amanah.

\section{SIMPULAN}

Terdapat relevansi dalam pembelajaran bahasa Indonesia di kelas X dalam kurikulum 2013 edisi revisi 2017, pada KD 3.8 Membandingkan Nilai-nilai dan kebahasaan cerita rakyat dan cerpen dan KD 4.8 Mengembangkan cerita rakyat ke 
bentuk cerpen dengan memerhatikan isi dan nilai-nilai. Melalui proses pengajaran cerpen Lelucon Para Koruptor, siswa dapat memahami tentang korupsi dan para pelakunya ketika di penjara. Pemahaman itulah yang dapat membangun karakter siswa dalam kehidupan sehari-hari bahkan di masa yang akan datang. Kelak mereka ditakdirkan sebagai pejabat yang jujur dan amanah.

\section{DAFTAR PUSTAKA}

Alwasilah, C. A. (2006). Pokoknya kualitatif. Jakarta. Pustaka Jaya.

Aminuddin. (2011). Pengantar apresiasi karya sastra. Bandung: Sinar Baru Algesindo.

Anisiannisa, U. E. (2013). Kritik sosial dan nilai pendidikan karakter dalam novel negeri para bedebah karya Tere Liye dengan menggunakan pendekatan sosiologi sastra (Skripsi). Surakarta: UNS

Departemen Pendidikan Nasional. (2015). Kamus besar bahasa Indonesia. Jakarta: Gramedia Pustaka Umum

Endraswara, S. (2008). Metodologi penelitian sastra. Yogyakarta: Medpress.

Esten, M. (2013). Kesusastraan pengantar teori dan sejarah. Bandung: Angkasa

Faruk. (2012). Metode penelitian sastra; sebuah penjelajahan awal. Yogyakarta: Pustaka Pelajar

Hartoko, D., \& Rahmanto, B. (2002). Kamus istilah sastra. Yogyakarta: Kanisius.

Mahayana, S. M. (2006). Bermain dengan cerpen; apresiasi dan kritik cerpen Indonesia. Jakarta: Gramedia Pustaka Utama

Marahimin, I. (2005). Menulis secara populer. Jakarta:Pustaka Jaya

Noor, A. (2017). Lelucon para koruptor. Yogjakarta:DIVA Press

Nurgiantoro, B. (2013). Teori pengkajian fiksi. Yogyakarta: UGM Press.

Pradopo, R. D. (2012). Beberapa teori sastra, metode kritik dan penerapannya. Yogyakarta: Pustaka Pelajar.

Pradopo, R. D. (1997). Prinsip-prinsip kritik sastra, teori dan penerapannya. Yogyakarta: UGM Press.

Rahmawati, E. W. (2015). Kritik sosial dan nilai pendidikan karakter dalam kumpulan puisi Doa Untuk Anak Cucu karya W S Rendara; kajian sosiologi sastra serta relevansinya sebagai bahan materi ajar sastra di SMA (Skripsi). Surakarta: UNS

Ratna, N. K. (2007). Teori, metode, dan teknik penelitian sastra. Yogyakarta: Pustaka Pelajar.

Ratna, N. K. (2010). Metodologi penelitian (kajian budaya dan ilmu sosial humaniora pada umumnya). Yogyakarta: Pustaka Pelajar.

Semi, A. (2001). Metode penelitian sastra. Bandung: Angkasa

Sudjiman, P. (1991). Memahami cerita rekaan. Jakarta: Pustaka Jaya

Sugiyono. (2014). Cara Mudah menyusun; skripsi, tesis dan disertasi. Yogyakarta: Alfabeth.

Sumardjo, J., dkk. (1986). Apresiasi kesusastraan. Jakarta: Gramedia.

Sumardjo, J. (1984). Cerpen Indonesia mutakhir antologi dan kritik. Jakarta: Gramedia 
Suroso, dkk. (2008). Kritik sastra. Yogyakarta: Elmatera Publishing.

Syamsi, N.. (2016). Nilai-nilai pendidikan karakter dalam Novel Ayahku (bukan) pembohong dan relevansinya terhadap karakteristik anak Usia SMP (Tesis). Jakarta: Unindra.

Taufiqurrahman. (2016). Kritik sosial, sasaran dan penyampaiannya dalam Cerpen "Pispot" karya Hamsad Rangkuti (Tesis). Jakarta: Unindra.

Teeuw. A. (2003). Sastera dan ilmu sastera. Bandung: Pustaka Jaya.

Wellek, R. \& Warren, A.. ed. Melani Budianta. (2014). Teori kesusastraan. Jakarta: Gramedia.

Zaidan, A. dkk. (2007). Kamus istilah sastra. Jakarta: Balai Pustaka

Haryanto. (2012). Pengertian pendidikan karakter (Online), Diakses dari belajarpsikologi.com/pengertian-pendidikan-karakter): diakses tanggal 18 Oktober 2016

Siska Permata Sari, (06 Agustus 2017). Manfaat membaca karya sastra. diakses Minggu 06 Agustus 2017 17:11 WIB

https://news.okezone.com/read/2017/08/05/65/1750472/nih-manfaat-membacakarya-sastra-apa-saja.

Steven, (2014). Sastra sebagai Kontrol Sosial. http.//jendelasastra.com/ wawasan/artikel/sastra-sebagai-kontrol sosial 